\title{
Navorsings-en oorsigartikels
}

\section{Oriëntering en navigering by voëls*}

\author{
H. Bouwman \\ Departement Dierkunde, Polchefstroomse Universiteit vir Christelike Hö̈r Onderwys, \\ Potchefistroom, 2520
}

Ontuang $15 \mathrm{Mei} 1997$; anwala 27 Okwober 1997

\section{UITTREKSEL}

Hoe voüls oor lang afstande kan navigeer en oriënteer; is een ran die aspekte van ormitologie wat heelwat belangstelling ontlok. Vö̈ls gebraik 'n kombinasie van verskeie inligtingsbromne om rigting en posisie te kam bepaal. Dit shit die geomagnetiese veld, hemelliggame, mosaiěk- en gradiëntkatarte, klank, reak, idiotetiese inligting en verskeie ander in. Verskillende spesies benut verskillende konbinasies van bronne. Hierdie vermoë blyk deels inherent en deels angeleerd te wees. Genetiese vaslegging van verskeie aspekte soos aanvangsrigting en koersverandering is ook angetoon. Hierdie artikel dui an dat datr nog heelwat aspekte is wat verder ondersoek moet word voordat 'n samehangende gehee/beed oor oriëntering en navige ring by voüls gevorm kan word.

\section{Abstract}

\section{Orientation and navigation in birds}

How birds orientate and navigate over long distances, remains one of the subjects of ornithology eliciting much interest. Birds use combinations of different sources of information to find direction and position. Some of these are the geomagnetic field, celestial bodies, mosaic and gradient maps, sound, smell, idiotetic information and others. Different species use different combinations of sources. This ability is partially inherent and partially learned. Aspects such as initial departure direction and course changes are genetic. This article shows that many aspects must be further researched before a coherent overview of orientation and navigation mechanisms in birds can be developed.

\section{INLEIDING}

Die kort en lang logte wat diere onderneem om van en na verskillende gebiede te beweeg, veronderstel 'n inherente vermoë om ten opsigte van eksterne en interne stimuli te kan oriënteer en navigeer, sodat tyd en posisic in ooreensteming gebring kan word met dic huidige en tockomstige behoeftes van die dier. Hierdie vermoë is veral by voëls baic duidelik waarneembaar,' maar geld ook vir baic ander diere. ${ }^{2}$ Deur die duur van die periode van migrasiconrustigheid ("Zugunruhe") van die Europese Wielewaal Oriolus oriolus en die Bont Vlieëvanger Ficedula hypoleuca in gevangeneskap met vliegspoed te kombineer, het Naumann reeds in die $18 \mathrm{de}$ ceu gespekuleer dat sckere voc̈ls na Afrika vlieg. ${ }^{3} \mathrm{Om}$ dit te kan doen, moet die voëls nie net kan rigting hou nic, maar ook hul posisie kan bepaal.

Om rigting te kan bepaal en die besiemming te kan bereik, onderskei Berthold ${ }^{3}$ twee konsepte, naamlik oriëntering en navigering. Oriëntering is die handhawing van rigting ten opsigte van eksterne stimuli soos dic aarde se magnectveld of sterre.
Navigering is die vind van opeenvolgende vaste punte en wegwysers soos berge, niebrocigebiede of spesilieke neste. Die volgende voorbeeld illustreer die verskil tussen die twee konsepte, alhoewel die twee nie wedersyds uitsluitend is nie.

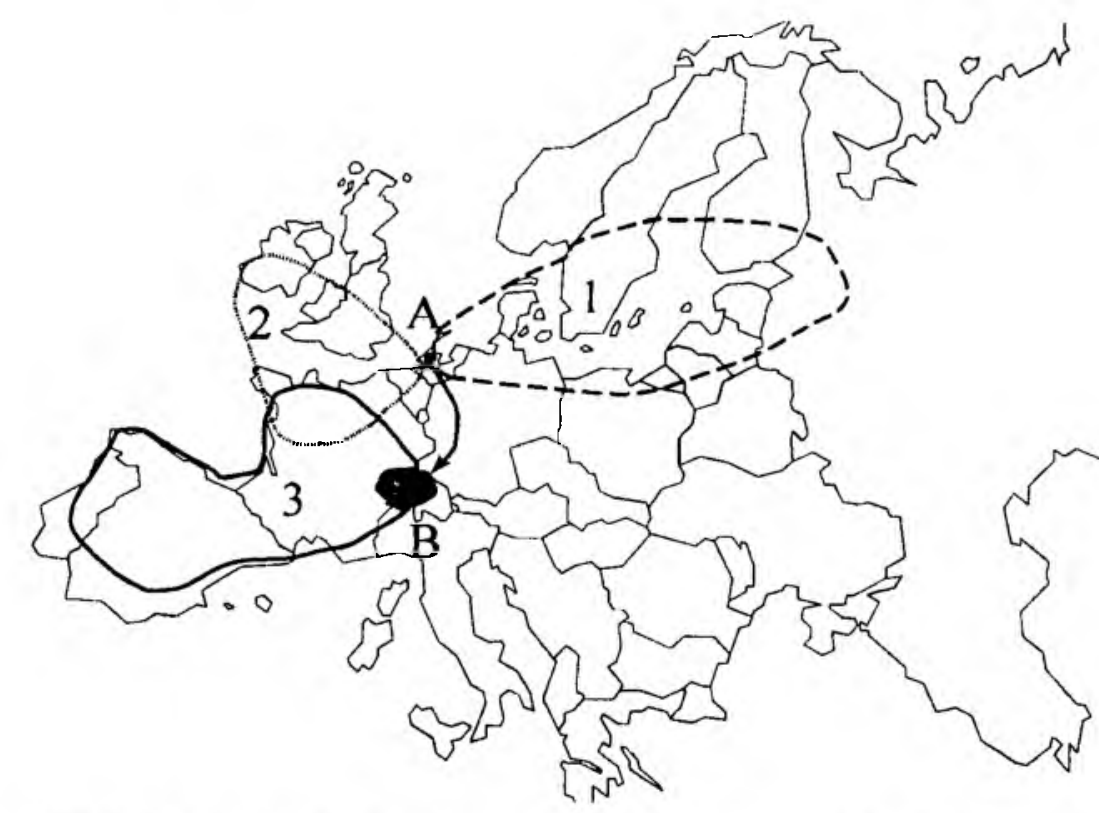

FIGUUR I: Individue van die Europese Spreeu Sternus vulgaris wat besig was om van hul broeigebiede (gebied I) na hul niebroeigebiede (gebied 2) te migreer; is by punt A gevang en na punt B geneem. By punt B is hulle vrygelaat. Die jong voëls het vervolgens gebied 3 bereik, terwyl die volwasse voëls wel na gebied 2 kon navigeer: 
Die Europese Spreeu Sturmus valgaris (wat in 1899 deur Cecil John Rhodes in Kaapstad vrygelaat is en teen 1973 reeds Durban bereik het ${ }^{4}$ ), is ' $n$ intra-Europese migrant. Verskillende brocibevolkings (geogralies gesien) in Europa migreer na verskillende, maar kenmerkende niebrocigebiede (sommige migreer selfs na Noord-Afrika ${ }^{5}$ ). Skandinawiese voëls migreer tipies na die noordelike dele van Wes-Europa (hig. 1). Ell' duisend van dié voèls is in Nederland tydens migrasic na hul nicbroeigebiede (Noord-Wes Frankryk, België en Suid-Engeland) gevang, bering, en in Switserland $(600 \mathrm{~km}$ loodreg van hul migrasieroete) weer vrygelaat." Dic jong voëls (op hul cersıc migrasietog) het parallel met die oorspronklike migrasieroete voortgevlieg, en het die suide van Frankryk, en die noordelike dele van Spanje bereik - nicbrocigebiede wat atipies vir die bevolking is. Die meeste volwasse diere he egter die verplasing geakkommodeer en noordwes gevlieg om hul oorspronklike en natuurlike niebrocigebiede te bereik. Die jong voëls het dus georiënteer en die korrekte rigting gehandhaat, malar dic ander gebied bereik. Dic ouer voëls hel egter wel vir die verplasing gekompensecr, hul oriëntering aangepas, en die regle bestemming, deur middel van navigering bereik. Dic jong voëls het op hul terugtog na die brocigebiede wel hul oorspronklike brocigebiede weer gevind, maar daarna teruggekeer na die nicbrocigebicde wat anvanklik verkeerdelik bereik is. ${ }^{3}$ 4. 0

Dit is dus duidelik dat daar heelwat meer meganismes van oriëntering en navigering ter sprake is, en dat wisselwerking tussen die twee voorkom. Vir die mens is dit moeilik om stimuli wat nie bewustelik deur ons waargeneem kan word nic, of nic vir orièntering of navigering gebruik word nic, te "visualiscer". Vlermuise, ${ }^{7}$ dolfyne, en voëls soos dic Grotwindswacl Aerodromus fuciphaga en die Olievoël Steatomis caripensis navigecr deur van eggolokalisering gebruik te mak" on dic omgewing te "visualisecr". Hulle "sien" dus deur van klank eerder as lig gebruik te maak. Die mens is hoolsaaklik visued ingestel, net soos ons in ons terminologie en algemene omgangstaal sekere aspekle visucel verwoord. "Visualiseer" verwys na 'n serebrale proses, terwyl die term "ck sien" kan verwys na die herkenning of erkenning van 'n konsep, sonder dal werklike sig noodwendig ter sprake kom.

Vlermuise, en in 'n groot mate ook dolfyne, is hoofsaaklik ouditories ingestel en "hoor" dus voorwerpe (of dic alwesigheid daarvan) soos ons sien. Net so vorm honde, wat $300000 \mathrm{keer}$ meer sensiticf vir sekere reuke is as die mens, 'n reukkaart bykomend tot dic visuele inligting. Mense, veral blindes, kan wel klank gebruik om te oriënteer en te navigecr, of om 'n indruk van die grootte van 'n ruimte of vertrek te kry, maar kan dit nie direk visualiseer nie. Dit word nog moeiliker indien stimuli soos magneetvelde en gepolariseerde sonlig, waarvoor die mens nie bewustelik sensitief (of sensiticf genoeg) is nic, ook ter sprake kom. Ons moct dus hesef dat, alhoewel dit vir ons makliker is om ons voor te stel dat visuele waarneming vir oriëntering of navigering makliker is as magnetiese waarneming, dit nic vanselfsprekend so vir diere is nic. Dit is belangrik om hicrdic menslike vooroordecl in ag te neem wanneer die sintuiglike aspekte van voëls (veral dic ouditoriese cn olfaktoriese) bespreck word.

Ander antroposentriese terme wat gereeld in die konteks van hierdic artikel gebruik gaan word (bv. kaart en kompas), mag dalk verwarrend wees, maar die gebruik hicrvan is beler as om alternaticwe terme te skep en te definicer. ${ }^{2}$ Ook gaan daar gereeld na diere anders as voëls verwys word. Ons huidige gebrekkige kennis aangaande oriëntering en navigering by voëls in dic besonder en ander diere in dic algemeen, noodsaak die verwysing na alternatiewe meganismes wat of nie by voëls beslaan nic óf nog nie waargeneem is nic
Nog 'n aspek wat uitgelig moet word, is dat sekere van die antroposentriese terme soos kies, selektecr, memoriseer, kompenseer en andere nie beskou kan word as doelbewuste oorwegings by diere soos by die mens nie. Dit veronderstel 'n "inherente bewustheid van self" by diere, en. alhoewel dit nie uitgesluit kan word nic," kan dit eerder as 'n inherente, niedoelbewuste proses beskou word.

Die doel van hicrdic artikel is om dic huidige, mar onvolledige kennis aangaande die meganismes wat voëls gebruik om te oriënteer en te navigeer, te beskryf. Ons weet dat voëls van dric tipes inligting gebruik mak om te oriënteer en te navigeer. Met inagneming van die konteks en antroposentriese oorsprong van die beskrywende terme, word dit biologiese kompasse, karte en interne programme genoem..$^{2.3}$

\section{BIOI,OGIESE KOMPASSE}

By voëls word kompasse beskou as die watarneming van eksterne stimuli wal gedurende die hele migrasieroele gebruik kan word om rigting te bepaal. Seker die bekendste navorsers in die verband is Wolfgang en Roswitha Wiltscko, tans by die Universiteit van Franklunt am Main. Die bevindinge van hierdic navorsers en verskeic ander, word hicronder weergegec.

Slegs twee brome van stimuli is globalal beskikbaar, naamlik die geomagnetiese veld en hemelliggame, en elkeen hiervan het sy eie dimensies walrvoor gedurende 'n lang tog gekompenseer moet word. "1)

\subsection{Die geomagnetiese kompas}

Dit is reeds sedert 1950 bekend dal voëls ten opsigte van die geomagnetiese veld kan oriëntecr. Een van die interessante wetenskaplike ontrafelings was om te bepaal hoe die verskillende dimensies van die geomagnetiese veld 'n rol speel in die oriëntasievermoë van voëls. Om dit te kan verstaan, moet daar eers na die eienskappe van die geomagnetiese veld gekyk word.

Die geomagnetiese veld van die aarde bestaan uit magnetiese veldlyne wat van pool tot pool om die aarde strek. Die pole hier ler sprake is nie die geografiese pole waarom dic aarde draai nie (rolasic-as), mar die magnetiese pole. Die Noord magnetiese pool is op $79^{\circ} \mathrm{N}$ in plaas van $90^{\circ} \mathrm{N}$ geleë; dic Suid magnetiese pool op $65^{\circ} \mathrm{S}$ in plaas van $90^{\circ} \mathrm{S}$. Verder is hierdie magnetiese pole nie staties nic, maar verskuif stadig teen 'n koers van sowat $1^{\circ}$ per dekade. Kleiner daaglikse variasies in die geomagnetiese veld kom as gevolg van sonaktiwiteit voor, asook plaaslike

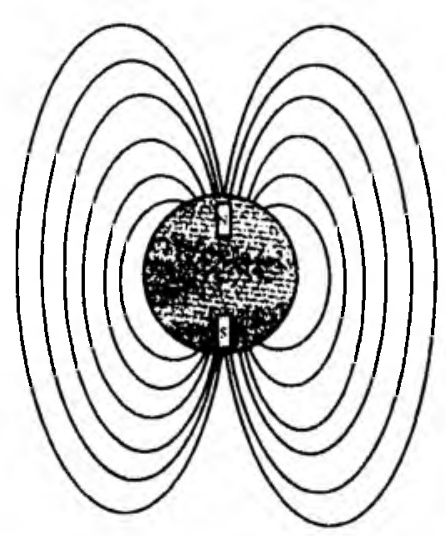

FIGUUR 2: Skematiese voorstelling ran die magnetokline. Magneriese veldlyne kom teen verskillende hoeke wit die aarde se oppervlakte. Hoe nader die veldlyne an mekaur is, hoe sterker is die magnetiese veld. 
afwykings as gevolg van geologiese lormasies. (Laasgenoemde kan moontlik addisionele inligting aangaande posisie verskaf met 'n mosaiëkkaart - kyk 3.1.) Gedurende die evolusionêre ontplooiing van voëls oor dic afgelope 150 miljoen jaart" het die Noord- en Suidpool ook verskcie maal van polariteit verwissel (m.a.w. noord met suid en omgekecrd), en dit mag weer gebcur.

Die geomagnetiese veld bevat drie meetbare dimensies wat potensieel bruikbaar is vir oriëntasic, naamlik: veldsterkte, polariteit en die magnetokline. Aangesien die drie dimensies lunksies van mekaar is, moel die onderlinge verband eers verduidelik word. Net soos die noord-en suidpole van magnete mekaar aantrek en gelyknamige pole mekaar afstoot, so verskil die eienskappe van die aarde se geomagnetiese pole. Hierdie polarisasic kan deur ' $n$ klassicke magnetiese kompasnaald onderskei word deur parallel met die veldlyne te oriënteer (fig. 2). Magnetokline is die hoek of ink linasic lussen die magnetiese veldlyne en die aarde se oppervlak. Naby die ewenaar is die lyne horisontaal met die oppervlak van die aarde $\left(0^{\circ}\right)$, mar nader aan die pole word die magnetokline stelselmatig groter todat

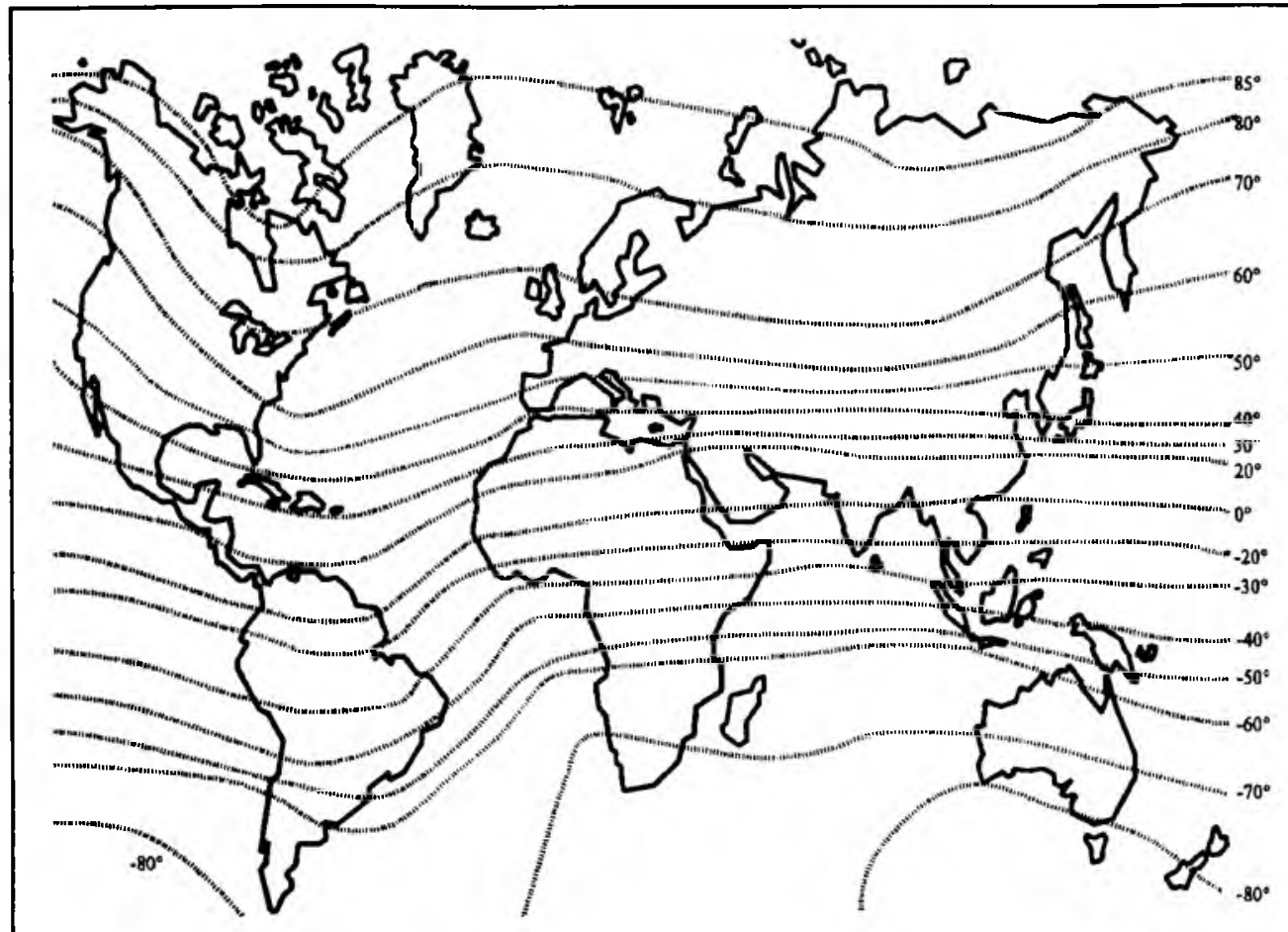

FIGUUR 3: Wêreldkaart van isomagnetoklines. Let op dat die magnetokline in die ongewing van die ewenaar ongeveer $0^{\circ}$ beloop.

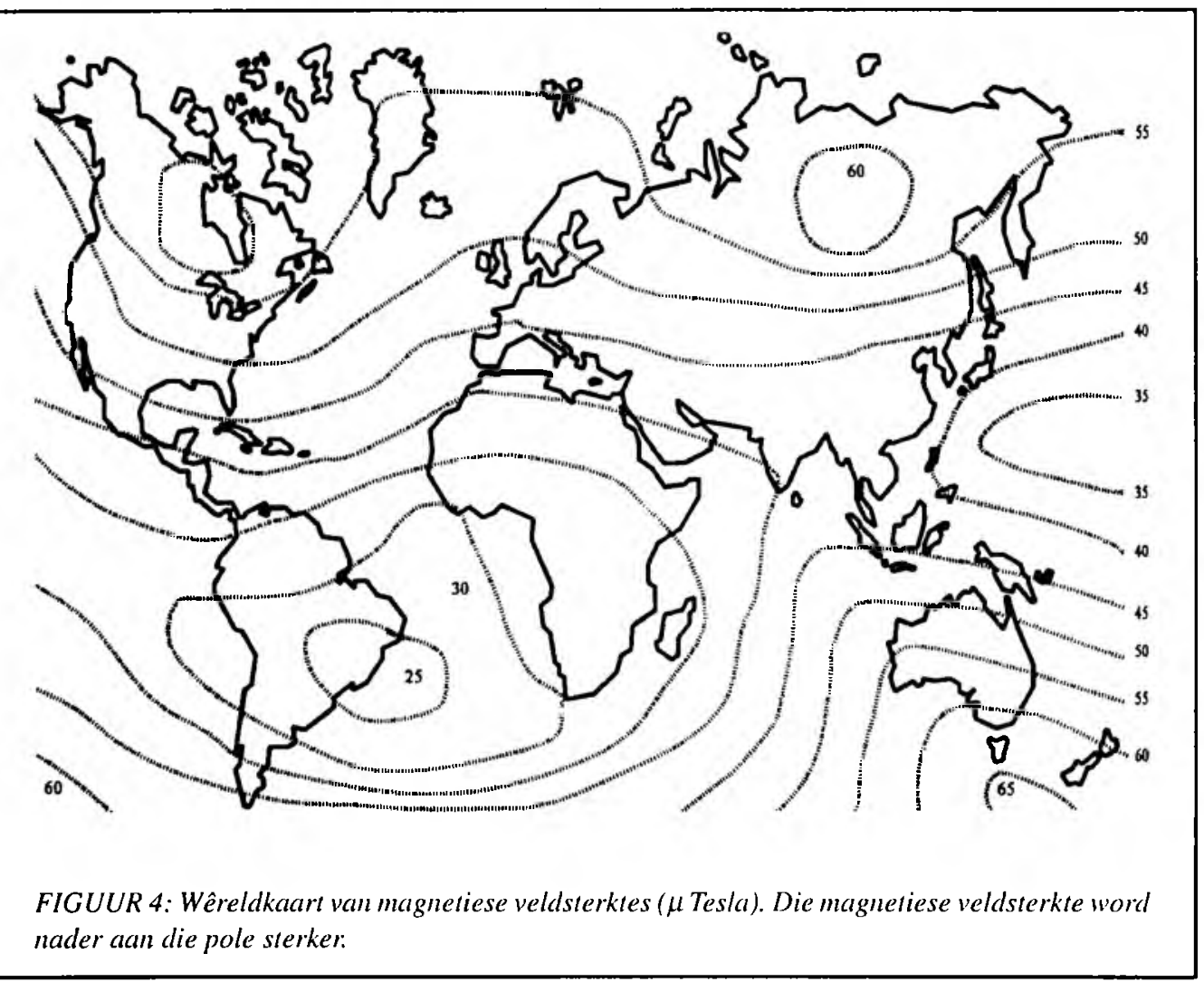


dit $90^{\circ}$ by die Noordpool en $-90^{\circ}$ by die Suidpool beloop. SuidAlrika se magnetokline is ongeveer $-70^{\circ}$ (fig. 3). Die veldsterkte, voorgestel deur die hoeveelheid lyne wat uit die aarde se oppervlak kom, neem nader alan die pole toe. Die geomagnetiese veldsterkte in die grootste gedeelte van Afrika is ongeveer 30 $\mu$ Tesla, terwyl dit in Skandinawië ongeveer $50 \mu$ Tesla beloop (lig. 4). 2, 10, 12, 13

\subsection{Veldsterkle}

Biologies is daar direkte en indirekte maniere om dic sterkte van die geomagneetveld wilar te neem. $\mathrm{Nel}$ soos 'n bewegende spocl in 'n magneetveld 'n ooreenstemmende elektriese veld induseer, so kan die beweging van seestrome in die aarde se magnetiese veld ook 'n elektriese veld tot gevolg he. ." Dit is bekend dat diere wel die vermoë het om elektriese velde walar te neem. Die integument van veral akwatiese diere isolecr die interne organe van die eksterne omgewing en veroorsala 'n elektriese veld om die dier in die vorm van 'n bilobiese dipool. Verskeic diere het elektriese sensors om prooi waar te neem deur middel van veranderings in hierdie elektriese veld. Dic hoek waarmee die seestrome deur die geomagnetiese veld beweeg, bepaal die sterkte van die elektriese veld en hiervolgens kan diere dan teoretics indirek oriënteer. Oriëntering op hicrdie manier word wel by rogge (Chondrichthyes) aangetref, maar by geen ander diere wat getocts is, insluitende voëls, kon delinitief bewys word dat elektriese of geomagnetiese veldsterktes vir oriëntering of navigering gebruik word nic. Verandering in veldsterktes as gevolg van magnetiese sonstorms versteur wel die migrasiepatrone van voëls, ${ }^{10}$ maar heclwat navorsing sal nog gedoen moet word om die invloed van magneticse veldsterkles te bepaal. Veldsterkles kom weer ter sprake wanneer kaarte bespreek word (sien afdeling 3 ).

\subsubsection{Polariteit}

Duiwe, waarvan die magnetiese veld rondom hul koppe deur middel van spocle verander is, raak op bewolkte dac gedisoriëntecrd. Eksperimente het ook aangetoon dat beide dag- en nagmigrerende voëls wel geomagnetiese inligting gebruik. Dit is bepaal deur enkelvoëls in Emlen-tregters te plaas. ${ }^{3}$ Dic voël in die tregter staan op ' $n$ inkkussinkie (fig. 5A). Wannecr die voël teen die kant van die tregter spring om uit te kom, laat die ink onder sy pote merke op die wande van die tregter (fig. 5B). Wannecr dic tyd aanbreck om te migreer (indien ons aanvaar dat dit 'n migrerende voël is), toon die voël 'n verandering in gedrag wat as migrasie-onrustigheid bestempel word, soos wat Naumann ook wargeneem het. Dit manifestecr as 'n neiging om mecr in 'n bepaalde rigting te spring (as gevolg van opeenvolgende pogings om te ontsnap) as enige ander. Hierdic voorkeurrigting kan maklik bepaal word deur dic plek wat dic meeste inkmerke op het as 'n kompasrigting te meet. Verder kan die magneetveld om dic tregter kunsmatig deur elcktriese spoele verander word om ' $n$ vals noord te skep en die verandering in lokus van migrasieonrustigheid as 'n ooreenstemmende rigtingverandering te meet. Verandering in voorkeurrigting kan dus bewerkstellig word deur die magnetiese noord te manipuleer. Ook kan die inklinasie na $90^{\circ}$ verander word, sodat geen inligting oor rigting beskikbaar is nic. Die twee hoofbevindinge van hierdie eksperimente was dat baie voëlspesies wel ten opsigte van die geomagnetiese veld kan oriênteer, maar dat polariteit as dimensie

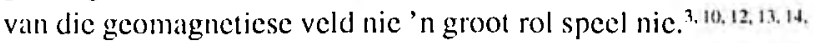
15

Die onvermoè om die polariteit van die geomagneticse veld te kan watarneen (of om daarop te reageer), het waarskynlik as gevolg van herhaalde polariteitswisselings gedurende die evolusionêre ontwikkcling van voëls ontstaan. Na elke wisseling was daar waarskynlik 'n natuurlike seleksicproses wat individue wat van polariteit gebruik gemak het, geëlimineer het. Polariteitsverwisselings, wat baie vinnig kan plaasvind, veroorsalak egter nie 'n permanente verandering in die inklinasiedimensie van die geomagnetiese veld nie, en die individue wat hierdie dimensie gebruik, sal dus beter oorleef, en die gene oordra aan meer suksesvolle nakomelinge.

\section{I.3 Magnetokline}

Voëls oriënteer dus nie deur lussen noord en suid te onderskei nie, maar hoofsaaklik ten opsigte van die magnetokline. Oriëntering is dus ten opsigte van 'poolwaarts' en 'ekwatorwaarts'. Hoe nader aan die ewenaar beweeg word, hoe minder inligting is egter beskikbalt om die twee te onderskei, aangesien die inklinasie nader aan $0^{\circ}$ neig, en min aanduiding van rigting op die manier heskikbaar is, ${ }^{2}, 10,12,13,14,15 \mathrm{Om}$ die magnetokline te kan bepaal, is 'n eksterne verwysingsralamwerk wel nodig en dit word waarskynlik deur die sigbare horison? ol swaartekrag verskal." 'n Aanduiding van hierdic wisselwerking is die feit Jat baic migrerende voëls tydens mis gedisoriënteerd raak. ${ }^{3}$

'n Magnetokliniese kompas bied ook 'n gedeeltelike teoretiese verklaring" hoe voëls die "grootsirkelroele" kan volg.' Gedurige koersaanpassings kan vir' $n$ lang gedeclte van die roete veroorsalak dat die voël 'n amper konstante inklinasic crvaar. Dit is vergelykbaar met die uitklim van 'n bolvormige heuwel (die helling word a! hoe kleiner nader aan die top), deur die helling waarteen geklim word, konstant te hou. Dic roete na die kruin is dus krom, en nic reguit nic.

\subsubsection{Wanneming yan die magneetveld}

Die volgende vraag wat ontstian, is hoe die magneelveld waargeneem word. Om die magneetveld te kan waarneem, is magnetiessensiliewe materiaal nodig. Biologies gesproke is daar vier moontlikhede wat as kompas kan dien, naamlik magnetiet, fotoreseptore, melanien en biogeniese radikale. ${ }^{3}$ Die laaste twee is in hicrdic stadium cerder hipotetics - oor die cerste twee is heelwat meer bekend.
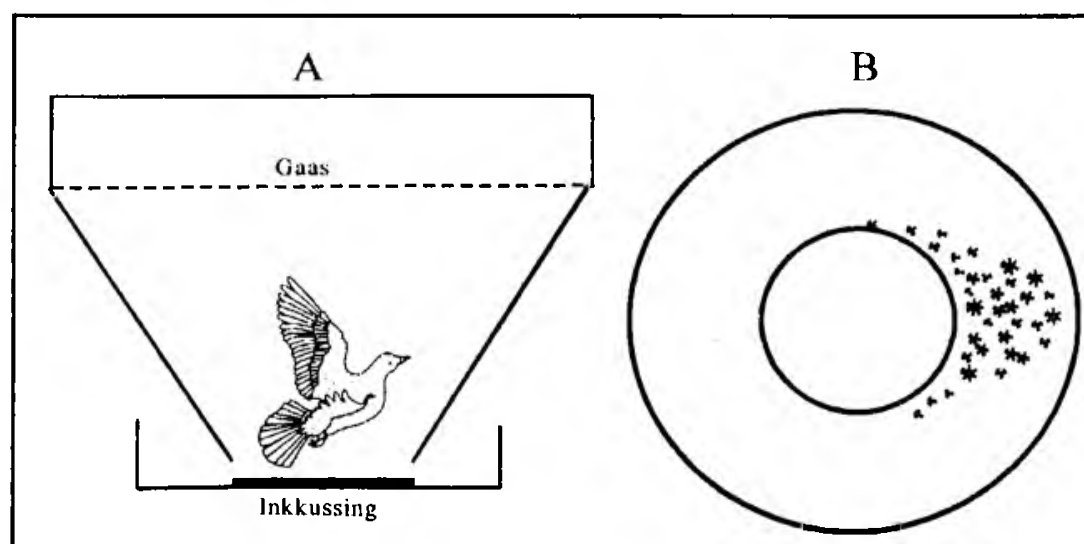

FIGUUR 5: Skematiese voorstelling vam 'n Emlen-tregter: $A$ is 'n sy-aansig en B 'n bo-aansig van die merke wat dear die pote van die voël op die wande gelaat is. 
Net soos klein magnete deur magnetiese pulse gercoriënteer kan word, so kan dic oriëntasierigting van dic Rysvoëltjic Dolichonyx oryzivorus' ${ }^{2}$ en 'n migrerende Glasogic (Zosterops lateralis $)^{16}$ met ongeveer $90^{\circ}$ verander deur magnetiese pulse aan die kop toe te dien. ' $n$ Magnetiese reseptor in die brein word dus gepostulecr en, alhocwel magnetiet ('n magnetiese matriaal; $\mathrm{Fe}_{3} \mathrm{O}_{4}$ ) in voëls se koppe aangetrel word, is die meganoreseptor nog nie gevind nic. ${ }^{2}$ Hicrdic materiaal kom op verskeic streke in die brein voor. Ongevecr $30 \%$ van die selle in die pineale streek van die duif se brein gec elcktricse reaksics op veranderinge in die horisontale of vertikale komponente van die aarde se magnetiese veld. Ysterbevattende weefsel kom ook aan die basis van die snawel naby die reuksintuie voor, asook elders in die kop. ${ }^{12}$ 'n Moontlike meganoreseptor wat sensitief genoeg behoort te wees, kan gevorm word deur 'n kombinasie van 'n biologies gevormde magnetictkristal en 'n haarsel, wat dic wringkrag uitgeoefen deur die magnetiese veld kan waarnecm. So 'n reseptor kan waarskynlik ook die hock tussen dic magnetokline en swaartekrag integreer. ${ }^{17}$

Die tweede moontlike manier van waarneming is deur middel van fotoreseptore in die retina. ${ }^{3}$ Die sensoriese selle van dic retina bevat pigmentmolekules waarvan die elektrone, indien dit deur lig van die regte golflengte getref word, na 'n hoêr energievlak beweeg. Hierdie molekules kan tcoreties as klein magnetc optrec cn inligting via die optiese senuwee aan dic brein verskaf. Dic Australiese ekwivalent van ons Glasogic is 'n migrerende voëlsoort. Onder gekontrolecrde toestande kan dié voël wel rigting bepaal in groen of blou lig, maar nic in rooi lig nie. ${ }^{18}$ 'n Kombinasic van 'n liggebaseerde en magnetictkompas in die kop van dic voël kan teoretics nie alleen rigting nic (ligkompas), maar ook dic posisic (magnctictkompas) bepaal deur variasie in veldsterkte te kan warneem. ${ }^{12}$

Alhoewel die magnetokline dus 'n kontinue bron van inligting bied wat nie aan sirkadiese of seisoenale verandering onderhewig is nie, kan dit nie orals, en ook nic in isolasie gebruik word nic. Ander verwysingsbronne is dus nodig om kocrs te kontrolecr en te kalibreer. Een van hicrdie bronne is dic posisic van die hemelliggame. Die son, maan en sterre word gebruik, maar soos reeds uit die vorige bespreking afgelci kan word, is dit ook nie 'n cenvoudige saak nic. Dic son, maan en sterre verskil van mekaar ten opsigte van velerlei eienskappe, en moet dus afsonderlik beskou word.

\subsection{Die sonkompas}

Die posisic van die son het vier dimensies, naamlik:

1) dic hoogte bokant die horison;

2) die rigting of asimut van die son, wat die geografiese rigting van die loodlyn van die son met die horison verteenwoordig;

3) die kompasrigting waar die son opkom en ondergaan en

4) die gedifferensiecrde polarisasie van die verskillende dele van die lug.

Vanuit die dier se konteks beweeg die son oor die hemelruim. Die bekendste voorbecld van 'n dier wat die son vir navigasic en oriëntering benut, is die heuningby. Die hock tussen dic asimut $\mathrm{en}$ die voedselbron word in ' $\mathrm{n}$ dans aan ander bye oorgedra wat daarna dieselfde rocte kan volg. Heelwat ander diere gebruik ook die son, maar dit blyk dat dic hoogte van die son as sodanig nic deur diere gebruik word nic. ${ }^{3,10,12,13}$

Wedvlugduiwe en die Swartbekpylstormvočl Puffinus puffinus is voorbeelde van voëls wat langer neem om na die nes terug te keer tydens bewolkte weer as in sonnige toestande. Eksperimente met sirkelvormige hokke waarvan die rigting van die son deur middel van spiec̈ls verander word, het ooreenstem- mende verandering in migrasic-rusteloosheid by die Europese Spreeu tot gevolg. Dic teenwoordigheid van 'n sonkompas is dus wel deeglik aangetoon, maar die gebruik van die son is nie 'n ecnvoudige proses nic. Eerstens is dic asimut van die son nie konstant nie, en tweedens verander die polarisiasic van sonlig ook gedurende die dag. ${ }^{2.3}$

\subsection{Asimut}

In teenstelling met die hoof saaklik statiese geomagnetiese veld is dic son as bron van inligting vir oriëntering en navigering siklics en nie konstant nic, aangesien dic asimut en hoogte kontinu, maar teen 'n nic-konstante koers verander. Die son beweeg leen 'n koers van $15^{\circ}$ per uur, "' maar die verandering in asimut is nie konstant nic. ${ }^{2}$ Soggens en saans is die kocrs van verandering stadiger, en vinniger in dic middag. Hicrdic daaglikse veranderinge is ook alhanklik van brecdegraad en seisoen. Dit beteken dat diere wat dic son gebruik vir hicrdic beweging moet kan kompenseer, en dit kan net gebeur indien tyd ook 'n rol speel. Sommige skoenlappers kompenseer nie vir tyd nie, maar miere, bye, visse en voëls beskik wel oor 'n tydgekompensecrde sonkempas. ${ }^{2}{ }^{10}$ Hierdic wisselwerking tussen tyd en son word onder andere bestudecr deur die sirkadiese ritmes (en dus ook tydsbewustheid of klok) van diere kunsmatig te verander en hierdie diere se oriëntasie ten opsigte van die son te voorspel, te meet en te vergelyk met dié van kontrolediere. ${ }^{2}$ 8,10

Op hierdie stadium weet ons van drie verskillende maniere hoe daar by die gebruik van 'n sonkompas vir tyd gekompenseer kan word. Sekere visse beskik oor een of ander inherente klok onalhanklik van die son. "Voëls en insckte gebruik byvoorbecld die asimut self as aanduiding van tyd, maar waarskynlik op twec verskillende manicre. Miere en bye interpoleer moontlik tussen verskeic opeenvolgende en gememoriseerde asimutposisies ten opsigte van fisiese kenmerke in die onmiddellike landskap, ${ }^{2} \mathrm{en}$ oriëntering word dus tot bekende gebiede beperk. Die eerste migrasictog (soos by voëls) kan dus nic hicrvolgens gebeur nic. Voëls memoriseer waarskynlik opeenvolgende posisies van dic asimut ten opsigte van 'n inherente klok ${ }^{10,19} \mathrm{en}$ kan dus tydens migrasie gedurig hiervoor kompenseer, aangesien die seisoen en brecdtegraad waar die voël hom bevind die koers van verandering gedurende die dag beinvloed. ${ }^{30}$

Die vermoë om tyd, seisoen en breedtegraad met dic asimut te kan integreer, word waarskynlik bepaal deur 'n inherente integreringsfunksic (elemerisfunksie) waarvan dic mate van akkuraatheid tussen verskillende diergroepe verskil. ${ }^{2}$ Bye is beter as micre, en voëls blyk ook oor 'n gocic cfemerisfunksic tc beskik, maar dic stand van kennis oor hicrdic aspek is nog gebrekkig. ${ }^{2}$ Onder cksperimentele toestande is die akkuraatheid van die tydgekompensecrde sonkompas vir wedvlugduiwe in die orde van $3,4-5,1^{\circ} .{ }^{3}$ Alhoewel hierdie vermoë van voëls om ten opsigte van die son te oriënteer en te navigeer wel inherent is, moet dit egter angelecr word. ${ }^{3}$

In die oog van dic voël is daar 'n kamagtige struktuur wat as die pecten oculi bekend staan en waarvan die grootte en vorm grootliks tussen spesies kan verskil. Die struktuur is geleë op die blindevlek, en is gepigmenteerd. ${ }^{20}$ Die waarskynlikste lunksic van dic pecten oculi is dic voorsiening van voedingstowwe aan die binnekant van die oog self. ' $n$ Ander moontlike funksie is die waarneming van die asimut. Die vorm en voorkoms vall die pecten oculi is sodanig dat dit teoreties 'n skerp omlynde skaduwee op die retina kan vorm in die omgewing van die beeld van dic horison. Dit kan dus die bepaling van dic asimut moontlik mak, maar hicrvoor is daar nog geen bewyse nic."1) 


\subsubsection{Polarisasie}

Dic son as sodanig is 'n direkte bron van lig, maar die gerellekteerde lig van die son word deur die mens net as blou lug gesien. Dic mate van polarisasie van die blou lug is verskillend op verskillende afstande van die son. Diere, soos bye en miere, mak hiervan gebruik om, indien hulle in skaduwee beweeg, nog steeds te kan oriëntecr deur na die polarisasic van sigbare gedecltes van dic blou lug te kyk. By voëls speel die oriëntasic van die gepolariseerde lig tydens sonsondergang waarskynlik 'n groot rol. Sommige spesies wat tydens die nag migreer, oriënteer die rigting van die komende nag se vlug ten opsigle van die ondergaande son. ${ }^{22,23}$ Tydens sonsondergang is die rigting van polarisasic ongeveer noord-suid. Dit gebeur wanneer die son reg in die weste ondergaan - 'n toestand wat tydens migrasieperiodes heers. Dié vorm van polarisasie gee egler geen aanduiding van welke rigting noord of suid is nic, en 'n addisionele bron van verwysing is dus nodig om die regte rigting le kan bepaal. Die posisie van die ondergalande son is in die geval dan die beste anduiding van welke van die twee rigtings noord of suid is. Ilierdie Iwec bronne van inligting word deur sekere voëls in kombinasic aangewend. ${ }^{2,10}$

\subsection{Die maankompas}

Ileclwat minder oor voëls se gebruikmaking van die maan as oor die son is bekend. Dic malan as verwysing vir oriëntering verskil in 'n paar opsigte van die son. Ecrstens is die maan net sigbaar vir die helfie van die nag, I weedens is daar maandelikse siklusse in terme van rigtings van beweging (nie jaarliks soos mel die son nie), en derdens is daar periodes van donkermaan wanneer die man nic duidelik sigbalar is nic. Sckere voc̈ls migreer net in die nagle wanneer die maan sighaar is, maar dit mag moonllik met beter sigbaarheid ecrder as met oriëntasie geassosicer wees. Ander voëls se migrasic word weer geinhibeer deur sterk maanlig, ${ }^{10}$ aangesien die sterre dan minder sigbaar is. ${ }^{3,8}$ Eende gebruik moontlik dic maan net soos dic son, ${ }^{3}$ maar wat dic omvang of belang hicrvan is, is nic duidelik nic."

'n Verdere aspek is dat maanlig ook gepolariseer is en dat dit 'n moontlike addisionele bron van inligting vir voc̈ls mag wees. Dic rigting van polarisasic is noord-suid $\left( \pm 28^{\circ}\right), \mathrm{cn}$ dit bly relatiel konstant deur die nag sodat tydkompensasic nie nodig is nic. Daar is egter nog geen dier bekend wat definitief hierdie inligling gebruik nic. Die mankompas word waarskynlik deur meer diere benut as walarvan ons bewus is, en heelwat meer navorsing kan dus nog hicroor gedoen word. ${ }^{3.10}$

\subsection{Die sterkompas}

Soos reeds voorheen gestel,' is die nag 'n gocie tyd om te migreer. Een van die voordele is die beskikbaarheid van die sterre as verwysingsbron. Sterre verskil van die son en maan in dié opsig dal dit meer as net 'n enkele punt in die lug is. Die tweedimensionele aard van die sigbare sterrehemel, gekoppel aan die nievariërende onderlinge patroon van sterre, bied meer inligting as die eendimensionele aard van die son of maan. Noord kan maklik van suid onderskei word, en om breedtegraad te bepaal, is tyd nie 'n faktor soos me dic son nie. ${ }^{10}$ Om die sterrehemel as kompas te kan verstaan, moet sekere aspektc hiervan eers verduidelik word.

Onalhanklik van sy cic rotasic, het 'n tol wat spin ook 'n sekondêre beweging indicn dit nie reghoekig mel dic oppervlak spin nic. Hierdic sckondêre beweging kan as 'n stadige beweging van dic rotasic-as van die bokant van die tol gesien word. en is baie sladiger as die rolasie om die 101 se eic as. Die rotasic-as verander dus gedurig. Aangesien dic alarde se rotasie-as met $23.5^{\circ}$ van die as valn simmetric ten opsigte van die son (oftewel die as van die aarde se rotasie om die son) verskil (fig. 6), roteer die rigling van die rolasic-as van dic aarde ten opsigte van die sterrehemel teen 'n koers van een omwenteling elke 25800 jaar. Dit beteken dat die rigting van dic aarde se rolasic-as, walarvan die noordelike decl op dic oomblik na die huidige poolster wys, stadig mat seker verander met 'n maksimum uitwyking van $47^{\circ}\left(2 \times 23,5^{\circ}\right)$ oor ' $n$ siklus van 25 800 jaar. llicrdie siklus word die presessie genoem. Boonop is die $23,5^{\circ}$ afwyking van dic rolasic-as met die simmetric-as ook nie konstamt nie, en ossilleer met 1,4 $4^{\circ}$ na weerskante van die $23,5^{\circ}$ hock oor 'n siklus van 41000 jalar. Die rigting van dic rotasie-as verander dus gedurig oor lang periodes. ${ }^{10}$

Gesien oor die 150 miljoen jaar van die evolusionere ontwikkeling van voëls" is dit egter moontlik dat selfs hicrdic periodes te kort is om die gedurige verwisseling van die poolster genelies vas te lê, deur elke keer op 'n ander spesilieke ster te fikseer as synde dic "poolster". ${ }^{\circ 0}$ Gedurende die mens se onlangse geskiedenis was daar net een poolster, naamlik alpha Ursae Minoris ol" Polaris in die sterrebeeld die Klein Beer. Drie-duisend jaar gelede was dit alpha Draconis of Thuban in die Draak. In die jaar 10100 sal dit alpha Cygni of Dench in die Swaan wees. Sou 'n spesificke ster as 'poolster' geneties gefikseer word, sou dic alwyking in rigling (tot $47^{\circ}$ van dic korrekte kocrs) van migrasie hicrlic individue deur natuurlike seleksic geëlimineer het. Die suidelike hemelruim het egter geen duidelike sterre wat die huidige rolasic-as kenmerk nie. Spesilieke sterre en sterrebeelde kan dus nie as 'n gocie rigtingwyser dien nie.

Die een aspek wat wel konstant en betroubatar is, is die punt van rotasic van die sterre rondom die rotasic-as (soos gesien vanal dic aarde). Aangesien die posisic vall die sterre ten opsigte van mekaar altyd konstant bly, is dic posisie van dic rotasic-as dié punt in dic sterrehemel waarom al dic ander sterre gedurende die nag roteer. In die hemelruim van die Noordelike Halfrond word dić punt gekenmerk deur Polaris in die sterrebecld dic Klein Beer, maar die Suidelike Hal frond toon net 'n donker kol. Dic voordeel verbonde aan dic gebruik van die sterpatroon (ckwivalent aan 'n voëlsterrebceld) om dic rotasic-as te bepaal,

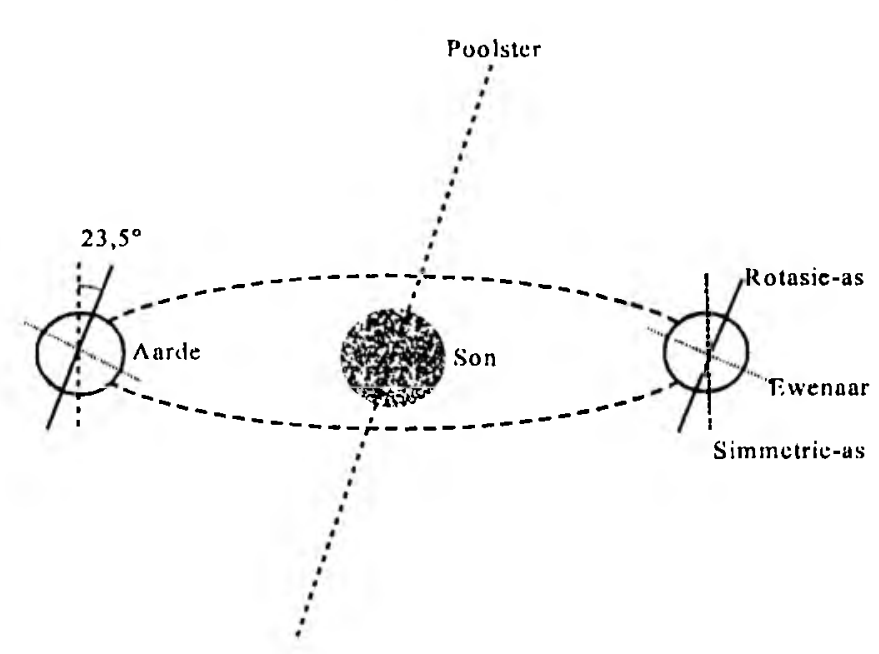

FIGUUR 6: Skematiese vorstelling on die verhouding van die ande se rotasie-as, simmertie-as en ewenatr ten opsigte van die son en poolster te illastreer: Let op dat die skema nie volgens skaal is nie - die poolster is so ver van die ande af dat die rotasie-as altyd na die poolster wys, ongeag van die wenteling van die carde on die son. 
is dat die effek van presessic nie 'n rol speel nie en dat geen tydkompensering nodig is nie. Die rotasic-as bly op 'n konstante posisie elke nag gedurende die hele lecltyd van enige organisme. Die verskuiwing van die rotasie-as as gevolg van presessie is te stadig om enigsins ' $n$ organisme te beïnvloed..$^{10}$

Alhoewel die belangrikheid van sterre reeds vrocër in oop hokke ondersock is, het Sauer in $1957^{24} \mathrm{en}$ Emlen in 1967.5 voëls se oriëntering in planetariums ondersoek. In een van die klassicke eksperimente in die biologie het onvolwasse, nagmigrerende voëls onder natuurlike (werklike sterre), sowel as onder kunsmatig korrekte sterre (planetarium), na dic magneticse suide georiëntecr. Toe die planetariumbeeld met $180^{\circ}$ gedraai is, het die voëls egter magneties noord, in die rigting van die kunsmatige rotasie-as gevlieg. Onvolwassenes wat onder 'n statiese hemelruim groot geword het, het egter nie 'n sterkompas ontwikkel nie. ${ }^{2.3,6,10,21}$

Emlen het nog verder gegaan en die rotasic-as vanal Polaris na alpha Orionis of Betclguese in die sterrebecld Orion kunsmatig verskuif. Onvolwasse Indigo Mossics Passerina cyanea wat onder die kunsmatige hemelruim grootgemaak is, het die rotasic-as vir oriëntering gekies. Selfs 'n totaal vreemde sterpatroon, bestaande uit net 16 sterre, bied genoeg inligting aan jong voc̈ls om die rotasie-as te kan bepaal. Nadat die rotasicas gememoriseer is, is rotasie self nie meer nodig nie en word die korrekte posisie van die rolasie-as ten opsigte van statiese. nieroterende sterre gekies. Nog verdere bewyse vir die gebruik van die sterpatroon om die rotasic-as te bepaal, het gekom deur sekere sterre uit die patroon te verwyder. Emlen het bewys dat verskillende individue van die Indigo Mossie verskillende sterpatrone (of voëlsterrebeclde) selekteer om die rotasie-as te kan bepaal. 2, 3. 10, 13, 25

Voëls wat oor die cwenaar migreer, sou egter nie voortdurend van die noordelike rotasie-as gebruik kan mak nie. Dit is moontlik dat 'n tydgekompensecrde sterkompas, gebaseer op voëlsterrebeclde naby dic sterre-ewenaar, gebruik kan word, maar dan moet die verskillende seisoene ook in ag geneem word. Die posisie van die sterrebeelde verskil tussen lente wanneer die voc̈ls hier arriveer en herfs wannecr hulle verırek. ${ }^{10}$ Of die rotasie-as van die suidelike hemelruim, alhoewel minder duidelik gemerk deur helder sterre, wel gebruik word, kon nie uit die literatuur vasgestel word nic, mar die moonllikheid bestaan wel.

'n Heel ander manier om te bepaal hoe voëls die sterrehemel gebruik om te kan oriënteer, is deur Emlen en medewerkers in 1978 gedoen. Witkeelmossies Zonotrichia albicollis (nagmigreerders in Noord-Amerika) is vanuit ballonne op onderskeidelik betrokke en helder nagte gedurende die lente-migrasicseisoen vrygelaat en met radar gevolg ('n radarweerkaatsende materiaal is aan huile vasgemaak). Die voêls wat op helder nagte vrygelaat is, het binne ' $n$ minuut die regte rigting gekies en 'n konstante koers gehandhaaf. Die wat onder betrokkc omstandighede vrygelaat is, het langer geneem om ongeveer in die regle rigting te vlieg. Heclwat het egter in sirkcls gevlieg. ${ }^{2}$ 3.4. 10

Sterre speel dus 'n belangrike rol in die oriëntering van voëls wat in die nag migreer. Dit is egter ook duidelik dat hierdic aspek, net soos met die sonkompas, 'n mate van leer vereis. Veral jong voëls het 'n spesifieke periode van sensitiwiteit waartydens die sterkompas ontwikkel word. ${ }^{8}$ Daar is al gesien dat kuikens van sterretjies en meeue op hul nes in die nag na dic hemel staar. ${ }^{21}$ Of dit spesifiek is om die rotasic-as waar te neem, is nie bekend nie. Dit is ook duidelik dat van die ander bronne ook ' $n$ rol specl. Die ander hoofbron van inligting, naamlik kaarte, moct ecrs bespreck word voordat die integrasic van dic verskillende bronne van inligting aandag kan geniel.

\section{KAARTH}

Een van die brocikolonies van die Swartbekpylstormvoël is 'n 100 ha-ciland naby Wallis waar 70000 individue voorkom. Nadat die kuikens uitgebroei het, bereik hulle 'n gewig van $50 \%$ meer as dié van hul ouers. Die ouers verlaal dan die eiland en word tien dae later deur die onvolwassenes gevolg. Waar hulle heengaan, is nic bekend nic, maar een onvolwassene is 13 dac later en $9600 \mathrm{~km}$ verder in Brazilie gevind $(738 \mathrm{~km}$ per dag). Die migrasie na Suid-Amerika is dus inherent en nic aangeleer nic. Twee tot vier jaar later, wanneer die jong voëls geslagsrypheid bereik het, keer hulle na die eiland terug en land binne $50 \mathrm{~m}$ van waar hulle uitgebroei het. Dit is onwaarskynlik dat die geomagnetiese of sterkompas akkuraat genoeg is om dieselfde posisie so presies weer terug te vind. ${ }^{10}$ I Ieelwat ander voorbeelde van akkurate terugkeer van individue na die vorige scisoen se broeiplekke is bekend. Grootstreepswacls Hirumdu cacullata keer gereeld na hul neste in Suid-Afrika terug nadat die nicbrocigebiede in sentraal Afrika besock is (cic waarnemings).

Akkurate navigering (in teênstelling met oriêntering) benodig 'n kaartgevoel waarbinne geheuekaarte saam met die dier sc eie ervaring ontwikkel. 'n Geheuekaart (net soos enige ander kalart) is 'n meganisme om inligting aangaande die ruimtelike verhouding (afstand en rigting, nie net rigting soos met kompasse nic) tussen bestemming en wegwysers te kan stoor en oproep. Van alle aspekte van migrering en navigering by voëls en ander diere is die kaartgevoel die een wat die minste verstaan word. ${ }^{10}$ Twee moontlike kaarttipes kan bestain, maar dit moct uitgewys word dat dit nic bekend is hoe die inligting gestoor of onterek word nic.

\subsection{Mosaiekkaart}

Die mosaiekkaart is 'n weergawe van dic ruimtelike verhouding van individucle landtekens soos berge, bome en rivicre op enige skaal van toepassing vir die organisme. Hierdie landtekens en afstande tussen landtekens moct deur clke organisme deur eksploratiewe togte geleer word. Indien die organisme buite die kaartgebied beland, sal die mosaïckkaart onbruikbaar wees. Vir voc̈ls mag dic mosaickkaart groter in omvang wees as bloot dic plekke wat reeds besock is. Dit is omdat groot landtekens soos berge, kuste en bome buite die spesificke ervaringsgebied nog steeds sigbaar is, sonder dal dil fisies besock is. Daar is dus ' $n$ vermindering in die mate van herkenning van landtekens hoc verder die organisme van sy blyplek (nes of slaapplek) af beweeg. Die ervaring met duiwe en ander diere toon dat sulke mosasïckkaarte (in welke vorm ookal), wel bestaan. ${ }^{2,3,10,13}$ Geen aanduiding van ' $n$ inherent aangebore mosaiekkaart, of enige ander kaart, bestaan nie. ${ }^{21}$ Onderliggend aan die vorming van 'n mosaickkaart, asook heclwat ander aspektc van migrering, is dat voëls ook visuccl moet kan waarneem.

\section{I.I Visie}

Dirckte visuele waarneming van landtekens en wegwysers is vir baie voëls van groot belang, nie net vir navigering en oriëntering nie, maar ook vir voedselvergaring, predatorontwyking en gedrag. Die sigskerpte (die vermoë om twee of meer visuele stimuli wat ruimtelik van mekaar geskei is, te kan onderskci) van voëls is nie so goed soos voorheen vermoed is nic. Roolvoëls se sigskerpte is in die algemeen beter as dié van dic mens, maar die sigskerpte van passeriene voëls en die wedvlugduif is swakker as dié van die mens. ${ }^{8}$

Sigskerpte is veral ter sprake wanneer hoofsaaklik dag 
aktiewe voëls nagmigrecrders is. Ilulle sigskerpte is goed genoeg om tydens die nag op groot hoogtes te kan vlieg sonder om teen ander migrerende voëls en berge vas te vlieg en om wegwysers soos kuslyne en riviere le kan waarneem, mar is nie goed genoeg om tussen lakke en ander obstruksies te kan vlieg nie. On sulke ongelukke te voorkom, begin en eindig baic hul nagtelike vlugte vanal boomtoppe of ander hoë punte vanwaar hul ook ander aspekte soos dic asinut en polarisasic kan waarneem. Of daar enig akkommodering vir nagvisic plaasvind, soos by die mens, is nog nie bekend nic. ${ }^{3}$

\subsection{Gradiëntkaart}

'n Gradientkaart is gebaseer op dic gradiënle van len minste twee lisiese veranderlikes wal sistemaltes oor groot afstande verander, ${ }^{3}$ maar nie noodwendig in diesellde rigting nie. Een manier om dit te visualiseer, is die verskillende hocke wiarmee konsentriese sirkels of ovale vanal twee verskillende oorsprongpunte mekaar kruis. Dit is dan teoretics moontlik om enige posisie te kan bepaal deur net na die hoeke van kruising te kyk. ${ }^{2}$ Een van die moontlike lisiese veranderinge is die magneticse veldsterkte en inklinasie, gekoppel met magneticse pole, ol swaartekrag. ${ }^{17}$ Alhoewel geen bewyse vir hierdie of enige ander kombinasie gevind kon word nie, word dit ook nie uitgesluit nic. $^{3}$

Ander moontlike bronne is dic asimut, windrigting, topografie en die patroon van golwe in oseane. Sekere ander bronne, soos reuke en geluide kan ook moontlik angewend word (4.2 en 4.3). Dic bruikbaarheid van hicrdic bronne is natuurlik gekoppel aan die omvang van die bron, dic kocrs van verandering van die gradiënte en sensoriese sensitiwiteit on die gradiënt te kan waarneem. Oor groot afstande sal die verandering in geomagnetiese veldsterkıe en ink linasic van waarde kan wees, terwyl die rigting van golwe en topografiese gradiente op kleiner skaal van nut kan wees.?

\subsection{Vektornavigering}

Aangesien vektornavigering onderlinge ruimtelike verhoudings behels, word dit in hierdie afdeling oor kaarte bespreck. Dic inligting wat deur dic dans van 'n by oorgedra word, naamlik rigting en afstand, staan as 'n vektor bekend. 'n Dier kan, nadat 'n kronkelweg gevolg is om voedsel te sock deur middel van 'n vektor, direk na die aanvangspunt terugkecr. Die omgekeerde van hierdic vektor is die afstand en rigting vanaf die aanvangspunt na die nuutgevonde voedselbron. Hierdie dier het dus net nodig om een vektor te kan stoor; dit is die cenvoudigste vorm van vektornavigering.

Diere besit ook moontlik die vermoë om meer as een vektor te kan kan benut om tussen meer as twee punte te kan beweeg. Dit kan ól deur vektorsommering ól deur vektorverskille bereik word. Gestel die dier beweeg vanaf die nes (punt A) na punt B en vandaar na punt $C$ (fig. 7.1). Om van $C$ na $A$ te beweeg, word die vektor van $B$ na die nes $(A B)$, en dic vektor vanaf $B$ na dic volgende punt (BC), gesommeer om vektor CA te kry. ${ }^{10} \mathrm{Gestel}$ egter die dier moet nadat hy punt B bereik het, 'n nuwe vektor vanal $\mathrm{B}$ na punt $\mathrm{C}$ bepaal (die posisie waarvan reeds aan dic dier bekend is), kan die vektor $B C$ verkry word deur $A C$ van $\mathrm{AB}$ af te trek (fig. 7.2)

Sckere mierspesies maak waarskynlik van vektorsommering gebruik. Dil is nog nie duidelik of die iweede meganisme. naamlik vektorverskille wel gebruik word nie. Daar behoort geen groot verskil tussen die twee meganismes in terme van kompleksiteit te wees nic. Die bestudering hiervan is nie maklik nic (trouens, nie vecl is nog hieromtrent gedoen nie ${ }^{10}$ ), want ander meganismes vall orientering of navigering (soos gepolarisecrde lig) kan ook 'n rol speel., 2.310 (Idioleliese navigering is 'n verwante konsep wat interne sintuie betrek, en word in 4.1 bespreck.)

Vektornavigering kan dus moontlik 'n rol by wedvlugduiwe specl (alhoewel 'n magnetiese kompas, sonkompas en ander orienteringsbronne ook 'n rol speel), asook mel dic voorbecld wall an die begin van die artikel genoem is oor die verplaasde Europese Spreeus se terugkeer na hul oorspronklike brocigebiede (lig. 1)."

\section{ANDER BRONNE VAN INLIGTING}

\subsection{Idiotetiese inligting (gisbestek)}

Dit is teoretics moontlik om elke beweging van 'n dier, insluitend positiewe en negaltiewe versnelling gedurende beweging, te kan integreer om sodoende die dier se posisie ten opsigte van sy alanvangspunt te kan bepaal. In die skeepvaart word dit gisbestek genoem. Darwin was die eerste bioloog wat hicrna verwys het. ${ }^{2.3}$ Die kinetiese inligting word versamel deur interne sensore soos spiersensore, kutikulêre spanningsensore (artropode) en die binne-oor (meeste gewerweldes). Korlatstandnavigering volgens hierdie idiotetiese meganismes word wel by diere soos insekte en soogdiere aangetref (by lg. is dit die binne-oor wat versnelling walaneem), maar of dit wel 'n rol by navigering by voëls speel, is nog nie bewys nie. ${ }^{3}$ Waar dil wel tydens migrasic 'n rol kan specl. is deur die dier in statat te stel om'n volgehoue vaste rigting te volg deur gedurig te kompenseer vir enige laterale bewegings wat deur die binne-oor wargeneem kan word.

\subsection{Ouditiewe inligting}

Geluide is moontlike brome van inligting wat vir oriëntering en navigering gebruik kan word. Verskillende habitatstipes toon tipiese geluidspektra wat veroorsaak word deur beweging van lug (wind), water (bv. golwe cn kabbelings) en organismes. Die beweging van wind deur berge, reënwoude en grasvelde veroorsalk aërodinamiese turbulensie wat gekenmerk word deur karakteristicke spektra van frekwensies as gevolg van hicrdic lurbulensie. Die spektra (Hz) en intensiteit van frekwensies (dB) variecr ook met die lyd van dic dag (a.g.v. geluidsaktiwiteit van diere) en wind. Die geluid van grasulaktes en berge word normaalweg gedomineer deur wind, lerwyl reënwoude gekenmerk word deur dieregeluide en die geritsel van blare. "Hierdie kenmerkende patrone kan dus dien as akoestiese kenmerke en wegwysers.

Om hierdie geluide as inligting vir orentering en navigering te kan benut, moet dit natuurlik waargeneem kan word. Die mens se frekwensie-omvang van walarneming strek van $20 \mathrm{~Hz}$ tol 12

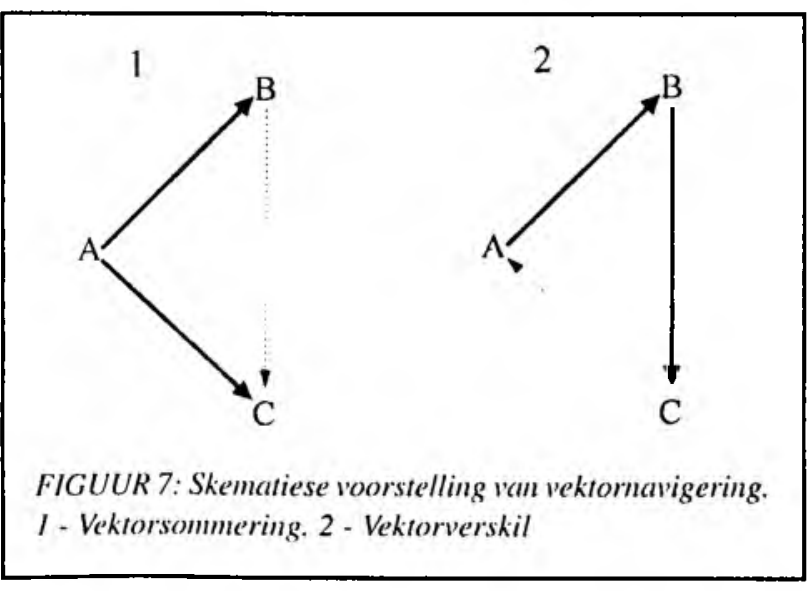


$\mathrm{kHz}(18 \mathrm{kHz}$ in jong kinders, $90 \mathrm{kll} \mathrm{z}$ in knaagdiere en $120 \mathrm{kllz}$ in vlermuise). ${ }^{3,10}$ Geluide met 'n lrekwensic van minder as 20 $\mathrm{Hz}$ word infrasonies genoem, en dic bokant $12 \mathrm{kHz}$ is ultrasonies. Dit is veral die infrasoniese geluide, veroorsaak deur turbulensic van wind deur berge, wat as gevolg van van die lang golflengtes van hierdie geluide, ook ver kan trek en stadiger verswak as geluide met korter golllengtes. Die frekwensic-omvang wat voëls kan waarneem is in die algemeen kleiner as die van die mens en strek vanal $600 \mathrm{~Hz}$ tot $11 \mathrm{kHz} .{ }^{\mathrm{x}}{ }^{10}$ Infrasoniese geluide kan egter wel $50 \mathrm{~dB}$ lacr as dic mens waargeneem word, met frekwensies so laag as $0,04 \mathrm{~Hz}$. Daar is ook voldoende alanduidings dat die wedvlugduif wel infrasonicse geluide kan waarneem, 3. 8.10 maar of dit via die oor gehoor word' en of dit deur tassensore (moontlk in die pote van die duif) gevoel word, ${ }^{x}$ is nie duidelik nie. ' $n$ Ander moontlikheid om infrasoniese geluide waar te neem en rigting le bepaal, is die gebruik van dic Dopplereffek. ${ }^{8}$ Deur net van fase- en intensiteitsverskille gebruik te mak, sou dic ore van 'n organisme ongeveer een kilometer uitmekaar moes gewees het. Deur vinnig genoeg in 'n sirkel te vlieg, gegewe dat die voël goed in toonhoogte kan onderskei. kan die rigting van die bron van infrasoniese geluide bepaal word. Ook moet die voël lussen bruikbare en niebruikbare infrasoniese geluide kan onderskei. Menslike akliwiteite, weerfronte en onweer, asook die beweging van lug oor die voël se cic vlerke, moet gefiltreer kan word.

Hierdic infrasoniese klanke, indien veroorsaak deur dic aërodinamiese turbulensic van wind deur bergreekse, oseane, reënwoude of ander bronne, kan dus as akoestiese wegwysers vir oriëntering en navigering dien aangesien dit baie ver kan trek. Geen definitiewe bewyse dat voëls dit wel benut, is egter beskikbaar nic. Heelwat meer navorsing sal nog gedoen moct word voordat navigering en oriëntering by voëls op grond van ouditiewe inligting bevestig of ontken kan word.

Verwant aan ouditiewe waarneming is die waarneming van verandering in barometriese druk. Wedvlugduiwe kan 'n verskil in barometriese druk van so min as $10 \mathrm{~m}$ in hoogte waarneem. ${ }^{10}$ Hicrdie vermoë specl waarskynlik 'n groot rol in die migrasicgedrag van voëls, veral vir die bepaling van dic aanvang van migrasic.

\subsection{Olfaktoriese inligting}

Olfaktoriese inligting word deur verskeic diergroepe, soos insekte, visse en soogdicre vir verskillende doeleindes gebruik. Dic bronne van die geurmolekules kan feromone en omgewingsgeure insluit. Vočlsoorte soos dic kiwi's, heuningwysers en sekere kraaic maak van olfaktoriese inligting gebruik om voedsel te vind. Die Swartpootmalmok Diomedia nigripes

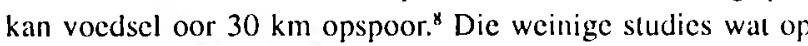
die reukvermoë van voèls gedoen is, dui in die algemeen aan dat die olfaktoriese vermoč nic baie goed ontwikkel is nic. ${ }^{3}$ Papi beweer egter dat wedvlugduiwe deur middel van reuk kan oriënteer en navigeer. ${ }^{2}$ Anosmiese duiwe (waarvan die reuksenuwee afgesny is) se navigering en oriëntering word wel geaffekteer en is nie so akkuraat soos voorheen nic. Ander eksperimente toon weersprekende resultate, veral wanneer dic resultate van verskillende eksperimentele protokolle wat dieselfde aspekte ondersoek, vergelyk word. 'n Moontlike verklaring vir hierdie digotomie is dat die geomagnetiese sensor, wat moontlik met die reuksintuie geassosieer is (2.4.1), geaffekteer word deur dic reuksenuwee af te sny.

Die groot atmosferiese vermenging en verdunning van reukmolekules wat gedurig plaasvind, is ' $n$ verdere rede waarom dit onwaarskynlik sal wees dat olfaksic gebruik kan word as inligting bykomend tot 'n mosaïek- of gradiëntkaart. Dic verdunningseffek benodig 'n baic sensitiewe reuksinutg. Alhoewel daar dus heel wal vrae omtrent olfaktoriese navigering bestaln, en heelwat outeurs verskillende sieninge hieromtrent handhaaf, ${ }^{3}+8$ kan dit moonlik eerder 'n rol speel op kotter alstande soos met die vind van 'n parmaat, nesmaat. bloed verwant of nesherkenning.

\subsection{Wind}

Op baic plekke in die wêreld is windrigtings sodanig konstant dat dit vir navigering gebruik kan word. Wund en die cienskappe daarvan (spoed, rigting, turbulensie, temperatuur en vertikale beweging a.g.v. warm stygende lugkolomme), het 'I groot rol in die ontwikkeling van migrasie en migrasieroetes gespeel en doen dit nog steeds. Windrigting kan tydens aanvang en gedurende vlug walargeneem word sodal die vlugrigting bepalal en gekorrigeer kan word, selfs sonder visuele verwysingsbronne. Idiotetiese inligting (4.1) kom natuurlik ook ter sprake, mar dalar is verskeic ander aanduidings dat voëls wind wel as inligtingsbron gebruik:"

1) Voëls kompenseer gedeeltelik vir laterale windrigtings, selfs in wolke gedurende die nag.

2) Voëls selekteer vir spesilieke hoogtes vir gunstige windrigtings.

3) Voëls, warvan die visie beperk is deur semideurlatende oogdoppe op te sit, het in die turbulensic wat deur dic vlug van ander voëls veroorsaak is, gevlieg.

4) Grondspoed is baie keer stadiger as die volgwindkomponent, selfs wanneer voëls oor die see vlieg.

5) Positiewe anemotakse by voels is ook al waargeneem.

Dil is nie bekend hoe voëls windrigting en -spoed tydens vlug kan waarneem nie, en ook nic hoe verspreid hierdic vermoë by voěls is nie. Twee moontlike meganismes is aan die hand gedoen om hicrdic vermoe te verklaar: ${ }^{3}$

1) Ouditicwe inligting (bv. golwe wat breek of subsonicse geluide van wind deur berge) kan as akoestiese wegwysers benut word. Aansluitend hierby is die addisioncle inligting wat verkry kan word deur die geluide wat gemaak word deur ander migreerders in vlug.

2) Anisotropiese patrone van turbulensic, veroorsaak deur die hock watartecn die voül deur die wind vlieg, kan moontlik waargeneem word. Dit is nie bekend hoe hierdic turbulensic waargeneem en die inligting verwerk word nic. ${ }^{3}$

\section{INTEGRERING VAN INI,IGTING}

In afdelings $2,3 \mathrm{en} 4$ van hierdie oorsig is die verskillende bronne van inligting wat werklik of potensicel deur voëls gebruik kan word, bespreck. Dit het egter reeds duidelik geblyk dat migrerende voëls meer as een bron moet en kan benul. Hoc hierdie inligling gebruik word, en welke hiervan die belangrikste is, is die onderwerp van hierdic afdeling.

Die gebruik van verskillende bronne van inligting kan gedurende die leeftyd van 'n voël verander. Verskillende spesies gebruik verskillende inligtingsbronne in 'n verskeidenheid van kombinasies. Sommige lê meer klem op magnetiese inligting, ander meer op 'n sterkompas of maak gebruik van kombinasies om die verskillende bronne van inligting met mekaar te kalibreer. Aangesien hierdie strategieë nog net by 'n paar voëlspesies ondersock is, is dic uiteenselting hicronder eerder sinteties en beperk deur ons huidige kennis. Dit mag wees dat ander laktore 
en kombinasies, soos geluid en reuk, by sekere spesies 'n groter rol speel as wat tans vermoed word.

Jong voëls leer die beweging van die son (insluitende die patroon van polarisasic) en sterre deur daarna te kyk en integreer dit met magnetiese inligting. Eksperimente het aanvanklik aangetoon dat visuele inligting (insluitende sterre, gepolarisecrde lig, asimut en kaartinligting) vir voëls van groter belang is as magnetiese inligting. Eksperimente gedoen op die Savannemossie Passerculus sandwichensis het die volgende getoon: Wanneer vier groepe jong Savannemossies elkeen blootgestel word aan kunsmatige naghemels waarvan ware noord volgens sterre (rotasie-as) na onderskeidelik magnetiese noord, suid, oos of wes wys, het die mossies daarna, sonder verdere sterinligting, na die onderskeic rigtings gevlieg. Die mossies het dus hul magnetiese kompas gekalibreer met dic "ware noord" in die sterre. ${ }^{12}$

Weindler het egter aangetoon dat jong Tuinsangers Sylvia borin, wal onder korrekte magnetiese en stcrinligting grootgemaak is, in die regte rigting, nl. suid-wes, vlieg. ${ }^{26}$ Dit stem ooreen met die aanvanklike rigting wat die Tuinsangers in Duitsland moet vlieg om om die Alpe na Spanje, en vandaar na Afrika, te vlieg. Dic wat egter net met korrekte ster-inligting grootgemaak is (die magnetiese veld om die hokke is met spoele geneutralisecr), het, nadat dic magnetiese veld weer herstel is, reguit suid gevlieg en sou oor die Alpe en Sahara moes migreer. Hierdic Tuinsangers het dus magneliese in plaas van visuele inligting verkies. ${ }^{2 b}$ Die vrylewende Tuinsangers wat verder oos in Europa voorkom, toon die omgekeerde, en vlieg suid-wes om Afrika via Libanon te bereik. Dit is egter waarskynlik dat hierdie voëls, gegewe genoeg tyd met korrekte ster- en magnetiese inligting, weer die regte rigting sal kies deur te herkalibreer: Dit is dan ook bewys dat selfs volwasse Savannemossies $90^{\circ}$. veranderinge in magnetiese veld kan akkommodeer.'

Daar is nog 'n probleem wat migrerende voëls moct oorkom - hoe verder suid (of noord) 'n voël vlieg, hoe minder bekend word die sterrehemel, terwyl die inklinasiehoek van die magnetiese veld verander. Die son se posisie verander ook. Weereens gebruik dic voëls die vermoë om te herkalibreer (ten minste die weinige wat reeds bestudecr is). ${ }^{12}$ Veral die eerste migrasietog is lank - tussen drie en vyf maande. ${ }^{3}$ Die daaglikse of nagtelike migrasievlugte is meestal kort, en die verandering in magnetiese, son- en sterinligting is stadig. Genoeg tyd is dus beskikbaar om te kan herkalibreer. Dat ' $n$ interne klok (ritmisiteit) 'n rol speel, is ook duidelik. Dit is onder andere aangetoon deur Tuinsangers lank genoeg onder magnetiese kondisies soortgelyk aan die trope in Emlen-tregters aan te hou. Na 'n ruk begin die voëls, wat aanvanklik suid gemigreer het, weer noord vlieg. Hierdic heroriëntasie kompenseer vir dic omgekeerde verandering in inklinasie wat die voëls moet ervaar op hul vlug suid - 'n heroriëntasic van nagenoeg $180^{\circ} .1^{12}$

Gedurende die eerste vlug van 'n migrerende voël kan kaarte (van welke aard ookal) ook gevorm word. Hierdie kaarte is egter beperk tot ervaring en kan vergelyk word met beperkte-inligtingroetekaarte wat in sommige padallasse gegee word, wat net die tersaaklike roetes, wegwysers en afstande gee.

\section{GENETIESE ASPEKTE}

Al bogenoemde aspekte het een onderliggende en fundamentele uitgangspunt, naamlik dat die voëls van die staanspoor af "weet" wanneer en in welke rigting om te vlieg, sonder dat daar (op enkele uitsonderings na) inligting lussen generasies uitgeruil word. Uitsonderings is byvoorbeeld swane en kraanvoëls wat in familiegroepe migreer, en waarvan die roetes moontlik van geslag tol geslag oorgedra word. Selfs in ander gevalle kan generasic-oordrag van inligting nie uitgesluit word nie - baie voèls migreer in groepe of los swerms. By wedvlugduiwe sal die individu met meer kennis van dic omgewing die voortou neem en voor vlieg, gevolg deur die ander. Hoe die duiwe weet wie meer weet, is nog onbekend. ${ }^{27}$ Aan die ander kant van die spektrum is die parasiticse voëls (veral koekoeke soos die Pietmy-Vrou Cuculus solitarius) wat ook migreer, maar sonder enige inligting of hulp van spesiegenole. Die jong voêls het nooit hul ouers gesien nic, maar "wect" wel waarheen om te vlieg. Hoe voëls die regte rigting kan bepaal, is dic onderwerp van hierdic alcleling.

Daar is al by meer as 20 spesies migreerders waargeneem dat die jong voèls spontane migrasie-onrustigheid in rigting en tyd ooreenstemmend met die aanvangsrigtings en -tye van vrylewende voels toon. Nie net is dit waargeneem vir migreerders nie, ook fakultatiewe migreerders (spesies soos die Grootmes Parus major, Gryskoppic Fringilla coelebs en die Swartlyster Turdus merula) wat net onder sekere omstandighede migreer, kies die regte rigting."

Dit wil dus voorkom of daar ' $n$ inherente (instinktiewe) geprogrammeerde doelrigting(s) in die voëls aanwesig is. ${ }^{28}$ Daar is heelwat alanduidings dat dit geneties is. Die beste bewys vir geneliese bepaling van migrasierigtings kom van Berthold, Helbig en die Wiltschko's. Eerstens het hulle Swartkroonsangers Sylvia atricapilla van Suid-Duitsland (migrecrders) met individue van diescide spesie, maar van die Kaap Verdiese Eilande (niemigreerders) gekruis. Die $F_{1}$-generasie het hul migrasie-onrustigheid georiënteer na die korrekte rigtings vir beide die heen- en terugmigrasic. In 'n opvolgeksperiment is individue van Suid-Duitsland (aanvangsrigting was aanvanklik suidwes) gekruis met individue van die ander kant van die migrasieskeiding (Oostenryk) waarvan die aanvangsrigling suidoos was. Die aanvangsrigting van die hibriede in die Emlentregters was suid, met ander woorde lussen die twee anvanklike rigtings van hul onderskeic ouers. Dit dui daarop dat migrasierigtings (vir ten minste dic Swartkroonsanger) additief is en waarskynlik poligeneties beheer word. 3. 29. 30. 31.32,33 Berthold en medewerkers" het ook alangetoon dat die neiging om te migreer deur kruisteling vanaf' $n$ migrerende bevolking van Swark kroonsangers na 'n niemigrerende bevolking (in die Kaap Verdiese Eilande) oorgedra kan word.

Nie net is die aanvangsrigtings geneties geprogrammeer nie, maar die geleidelike kocrsanpassings gedurende migrasie is waarskynlik ook geneties vasgelê. Tuinsangers en Swartkroonsangers (met 'n natuurlike suidwes-aanvangsrigting) wat gedurende die migrasieperiode in Emlen-tregters aangehou is, verander die voorkeurrigling vanal suidwes na suid. Dit is in ooreenstemming mel dic koersaanpassing van die vrylewende voëls op die sladium wat hulle Noord-Alrika bereik het. Hicrdie waarneming versterk dan ook die aanname van 'n inherente $\mathrm{klok}^{3,13,19}$ sodat die voëls op die regle lyd gereed is om te vertrek, tydige koersaanpassings maak en op die regte tyd stop.

Vir sommige voëls soos dic Hofsanger P/y/loscopus trochilus is dit teoreties nic meer nodig om so ver suid na Afrika te migreer nie. Die laste ystydperk was 10000 jaar gelede verby en gunstige toestande is tans in Asië aanwesig. Geen variasie of mutasic het dus intussen ontstaan om die rigting te verander nic. ${ }^{3}$

Aan die ander kant het daar waarskynlik vinnige genetiese veranderinge in migrasierigting by die Swarkroonsanger ontstaan. Normalalweg migreer Wes-Europese voëls suidwes na hul niebrocigebiede in Noord-Afrika. Dic Oos-Europese voëls migreer suidoos na Oos-Afrika. Onlangs het egter meer en meer Oos-Europese Swartkroonsangers in die VK begin oorwinter. Hierdic verskynsel is waarskynlik toc te skryf aan enkele 
dwaalgaste (geneticse variasies) wat begin voordecl trek hel uit die Engelse voëlliethebbers se gewoonte om veral in die winter voëls te voer. Hierdie onnatuurlike voedselbron gec tans alanleiding dat meer voëls wat in plaas van suidoos migreer, nou wes oor 'n korter al'stand migreer. Hierdie voëls word deur dic voedselbron en korter migrasic-afstand bevoordecl. 'n Beter oorlewing van hicrdic individue van die Oos-Europese bevolking neig dus om deur natuurlike seleksie meer suksesvolle individue te produseer, en die getalle van wes-migreerders neem toe. ${ }^{30,34}$

Hierdie genetiese aspekı is ook van belang indien dalar gekyk word na die bedreigings waaraan migreerders onderworpe is. Bevolkings wat groot genoeg is (en dus uit 'n groter genetiese variasie kan voordecl trek) om by bedreigings soos klimaatsveranderinge of habitatsvernietiging le kan aanpas, sal deur verandering in migrasieroetes kan oorlecf. Ander sal egler nie kan aanpas nie en uitsterf. Dit kan veral die lol wees van kleiner bevolkings (soos die Blouswael Hirundo atrocaerulea') of bevolkings met lang generasietye soos kraanvoëls en ooievaars. Net 'n volgehoue navorsings- en moniteringspoging deur beide professionele' en amateuromitoloẻ sal sulke veranderinge tydig kan waarneem om suksesvolle bewaringsmaatreèls te kan instel.

\section{SAMEVATTING}

Deur die ceue heen het die mens telkens te staan gekom voor die raaisel $\mathrm{en}$ bewondering wat die migrasic van veral voëls teweeg bring. Met die tyd is meer en meer van hierdic onbekende verskynsels opgelos of beter gedefinieer. Hoe mecr egler te wele gekom is, hoe mecr nuwe vrac is gestel. In hicrdic vrae waarvan die antwoorde ons ontgaan, en selfs nuwe vrae wat ons nog nie van weel nie, lê ongetwyfeld oplossings vir die mens se huidige of tockomslige probleme, moontlik sclfs dic ontsluiting van onbekende of ongebruikte sensoriese persepsies in dic mens.

Die mens is op baic terreine in wisselwerking met voëls. Dit sluit in wetenskap, ekonomic, sport, religie, kultuur en transport, maar die een faktor wat alle mense saambind, is sy cstetiese verbintenis met voëls. Van alle organismes is voëls cen van dic bekendste en mins gevaarlike diere vir die mens. Behalwe soogdiere is voëls die enigste ander klas organisme wat endotermies is. Soos honde en katte word voëls as troeteldiere in huise aangehou. In die VSA word meer as $\$ 900000000$ jaarliks aan voëlkyk bestec. Min ander organismes (behalwe vocdselplante) het so 'n noue verbintenis met die mens. Dat $11 \%$ van die voëlspesies tans globaal met uitsterwing bedreig word, is 'n koue herinnering aan die stand van die planeet wat ons met hulle deel.

\section{Summary}

Birds are able to use different mechanisms to navigate and orientate during migration. Navigation is the sequential location of intermediate fixed points that lead towards a goal. Orientation is the ability to maintain direction using mainly external stimuli such as the geo-magnetic field or stars. A number of different ways are available to implement this information. Stimuli can be used as compasses, maps, and in combination with internal programmes.

The main sources of information regarding biological compasses are the geomagnetic field, stars, the sun and the moon. Of these, the most important seem to be the geomagnetic lield and stars, but a significant role is also played by the sun. The angle of inclination of the geomagnetic field, the rotation axis of the earth and the azimuth of the sun are dimensions appar- ently mostly used by birds. These dimensions seem to be the most stable of the available dimensions from each information source, enabling birds to migrate even during severe disruption, e.g. a change in polarity of the magnetic field of the carth. These sources have different properties needing different ways of perception and integration, and birds are able to use them. However, the methods of sensory pereption, or the mechanisms that integrate the intormation, is not well understood.

A map sense also secms to play a significant role, but even less is known about this ability. Two possible types of map sense could be used. A mosaic map is a mental storage of the relative spatial relations of individual sites or landmarks. A gradient map is based on the attenuation of at least two independent physical changes that alter systematically over large distances. This could include aspects such as the azimuth, the geomagnetic lield or wave patterns on oceans. The angle of intercepts between these gradients also changes systematically, offering a theoretical way of detcrmining position.

Other sources of information include idiothetic (intemal), auditory and ollactory information, as well as aspects of wind and social interaction.

Many migratory birds are able to integrate information from various sources, and seem to calibrate the one against the other. Some birds, for instance, use the rotation ax is to determine general direction which is then modified by information gained hrom the geomagnetic field. Young birds seem to have an inherent tendency to assimilate aspects such as the stars in the night sky and inclination angles and are even able to modily their migratory behaviour later in lile when challenged by artilicial changes in these components. There is also a genetic involvement programming the birds to follow specilic departure directions, cued on external sources such as the geomagnetic lield, at determined times based on internal physiological clocks and external changes in weather.

It is, however, abundantly clear that much remains unknown about the abilities of birds and other animals to find their way over long distances. It will lake much more research to eventually be able to present a coleerent vicw of how birds are able to orientate and navigate.

\section{Bedanking}

Ek bedank Beatrix Bouwman en Pieter Theron graag vir verbeterings aan dic artikel.

\section{LITERATUURVERWYSINGS}

I. Bouwman, H., Evans, S.W. (1997) Die migrasic en bewaring van voëls in 'n Suider- Alrikanse konteks. $S$. Afr: Tydskr: Narmurwet. en Tegnol. 16,4, 150-1.59.

2. Papi, F. (1992). Animal homing (Chapman \& Hall, London).

3. Berthold, P. (1993). Birdmigration: A general survey (Oxlord University Press, Oxford)

4. Maclean, G.L. (1990). Ormirhology for Africa (University of Natal Press, Pictcrmaritzburg)

5. Delin, H., Svenson, L. (1990). Photographic glide to the birds of Britain and Earope (Hamlyn, London).

6. Perdeck, A.C. (1958). Two types of orientation in migrating starlings, Sturmus r'mlgaris L., and chaffinches, Fringilla coelebs L., as revealed by displacement experiments, Ardea, 46, 1-37.

7. Dawkins, R. (1986). The blind watchmaker (Penguin Books, London).

8. Brooke, M., Biskhead, T. (1991). The Cambridge Encyclopedia of Omithology (Cambridge University Press, Cambridge).

9. Goodall, J. (1990). Through a window (Weidenfeld and Nicolson. London).

10. Dusenbery, D.B. (1992). Sensory Ecologv (W.H. Freman and Com- 
pany, New York).

II. Benton. M.J. (1990), Verrebrate paleomology (Ilarper Collins Aciademic, London).

12. Pool, R. (1996) Is it a plane? Is it a bird? New Scientist, 2055, 29. 32.

13. Elphick, J. (1995). Collins atlas of bird migration (Harper Collins, Uniled Kingdom).

14. Munro, U., Wiltscliko, W. (1993). Magnetic compass oricutation in the yellow-faced honeyeater, Lichenostonus chrysops, a day migrating bird from Australia, Behav. Ecol. Sociobiol., 32, 141-145.

15. Wiltscliko, W., Munro, U., Ford, II., Wiltschko, R. (1993). Magnetic inclination compass: A basis for the migratory orientation of birds in the northern and soulhern hemisphere, Experientia, 49, 167 . 170.

16. Wiltschko, W., Munro, U., Beason, R.C., Ford, H., Wiltschko, R. (1994). A magnetic pulse leads to a temporary deflection in the orientation of migratory birds, Experientia, 50, 697-700.

17. Edmonds, D.T. (1992). A magnetite null detector as the migrating bird's compass, Proc. R. Soc. Lomd., Series B. Biol. Sci., 249, 27 31 .

18. Wiltsclıko, W., Munro, U., Ford, H., Wiltschko, R. (1993). Red light disrupts magnetic orientation of migratory birds, Nature, 364, 525 527.

19. Munro, U., Wiltschko, R. (1993). Clock-shift experiments with migratory yellow-faced honeyeaters, Lichenostomus chrysops (Mcliphagidac), an Australian daly-migrating bird, J. Exp. Biol., 181 , 233-244.

20. Alerstam. T., Pettersson, S.G. (1991). Orientation along great cilcles by migrating birds using a sun compass, J. Theor: Biol., 152, 191-202.

21. Bright, M. (1993). The prisate life of birds (Bantam Press, London)

22. Able, K.P., Able, M.A. (1993). Daytime calibration of magnetic orientation in a migratory bird requires a view of skylight polarization, Nature, 364, 523-525.
23. Phillips. J.B., Moore, F.R. (1992). Calibration of the sun compass by sunset polarized light patterns in a migratory bird, Behat: Ecol. Sociobiol., 31, 189-193.

24. Sauer, E.G. (1957). Die Sternenorienticrung nächulich ziehender Grasmiicken (Sylhia atricapilla, borin und carraca), Z. Tierpsychol., 14. $29-70$.

25. Emlon, S.T. (1967). Migratory orientation in the Indigo Bunting, Passerina cyanea, Auk, 84, 309-342.

26. Weindler, P., Wiltschko, R., Wiltschko, W. (1996). Magnetic information affects the stellar orientation of young bird migrants, $N$ ature, $383,158-160$

27. Barnell, A. (1997). Pigeons follow my leader, New Scientist, 2080,18 .

28. Helbig. A.J. (1992). Ontogenetic stability of inherited migratory directions in a nocturmal bird migrant: Comparison between the first and second year of life, Ethol. Ecol. Evol., 4, 375-388.

29. Berthold, P., Wiltschko, W., Miltenberger, H., Querner, U. (1990). Genctic tansmission of migratory behavior into a nonmigratory bird population, Experiemia, 46, 107-108.

30. Helbig, A.J. (1991). SE- and SW-migrating blackcap (Sy/via arricapilla) populations in Central Europe: Orientation of birds in the contact zone, J. Evol. Biol., 4, 567-670.

31. Helbig, A.J. (1991). Inheritance of migratory direction in a bird species: A cross-breeding experiment with southeast-migraling and southwest-migrating blackcaps (Sylvia atricapilla), Behan, Ecol. Sociobiol., 28, 9-12.

32. Helbig, A.J. (1992), Population differentiation of migratory directions in birds: Comparison between ringing results and orientation behaviour of hand-raised migrants, Oecologia, 90, 483-488.

33. Berthold. P., Pulido, F. (1994). Heritability of migratory activity in a natural bird population, R. Soc. Lond., Series B. Biol. Sci., 257, $3|1-3| 5$.

34. Berthold, P., Helbig, A.J., Mohr, G., Querner, U. (1992). Rapid microevolution of migratory behaviour in a wild bird species, $\mathrm{Na}$ Iture, 360, 608-670. 